\title{
Strategi Alokasi Anggaran Dinas Kesehatan Kota Bogor Di Era Covid-19
}

\section{Budget Allocation Strategy of Bogor City Health Department in the Covid-19 Era}

\author{
Tia Revinadewi*) \\ Dedi Budiman Hakim \\ A. Faroby Falatehan \\ Fakultas Ekonomi dan Manajemen IPB, Jawa Barat, Indonesia \\ Email : dwrevina12@gmail.com
}

\begin{abstract}
The authority of the local government in the Replacement Government Law No. 1 of 2020 is that the Local Government is given the authority to prioritise the use of budget allocations for certain activities (refocusing). One of the areas in Indonesia affected by Covid-19 is Bogor City, Bogor City is one of the cities close to the capital and becomes one of the cities with transmission through imported cases originating from outside the region. The proportion of bogor health budget in 2020 is prioritized for Covid-19 prevention. The purpose of this study explains the state of the budget of the Bogor City Health Office during Covid-19 and explains the use of the Covid-19 budget in accordance with the objectives and formulates a budget allocation strategy based on the existing budget. The type of dtaa used in this study is primary data obtained through in-depth interviews with virtue takers related to using analytical hierarchy process $(A H P)$ questionnaires and secondary data obtained from the Health Office, Regional Planning and Development Agency and Bogor City Asset Finance Agency.
\end{abstract}

Keywords: Analytical Hierarchy Process (AHP), Covid-19, Reallocation and Refocusing

\begin{abstract}
ABSTRAK
Kewenangan pemerintah daerah dalam Pemerintah Pengganti Undang-Undang Nomor 1 Tahun 2020 adalah Pemerintah Daerah diberikan kewenangan untuk melakukan pengutamaan penggunaan alokasi anggaran untuk kegiatan tertentu (refocusing). Salah satu daerah di Indonesia yang terdampak Covid-19 adalah Kota Bogor, Kota Bogor merupakan salah satu kota yang dekat dengan Ibukota dan menjadi salah satu kota dengan penularan melalui imported case yang berasal dari luar daerah. Proporsi anggaran kesehatan Kota Bogor di tahun 2020 yang diprioritaskan untuk penanggulangan Covid-19. Tujuan penelitian ini menjelaskan keadaan anggaran Dinas Kesehatan Kota Bogor saat Covid-19 dan menjelaskan penggunaan anggaran Covid-19 sesuai dengan tujuan serta merumuskan strategi alokasi anggaran Dinas Kesehatan berdasarkan anggaran yang ada. Jenis dtaa yang digunakan dalam penelitian ini adalah data primer yang diperoleh melalui wawancara mendalam dengan pengambil kebajikan
\end{abstract}


yang terkait dengan menggunakan kuesioner Analytical Hierarchy Process (AHP) dan data sekunder diperoleh dari Dinas Kesehatan, Badan Perencanaan dan Pembangunan Daerah dan Badan Keuangan Aset Daerah Kota Bogor.

Kata kunci : Analytical Hierarchy Process (AHP), Covid-19, Realokasi dan Refokus

\section{PENDAHULUAN}

Pemerintah Indonesia pertama kali mengumumkan kasus Covid-19 pertama kali masuk ke Indonesia pada tanggal 2 Maret 2020. World Health Organization (WHO) menyatakan bahwa gejala pengidap virus corona (Covid-19), yaitu demam, batuk, sakit tenggorokan, merasa lelah terus-menerus dan sesak napas. Covid-19 adalah virus yang menyerang sistem pernapasan manusia dan yang membedakan virus ini dengan virus lainnya adalah Covid-19 memiliki virulensi atau kemampuan yang tinggi untuk menyebabkan penyakit yang fatal.

Pemerintah Indonesia melakukan upaya menanggulangi Covid-19 dengan fokus di sektor kesehatan dan stabilitas ekonomi nasional, yaitu dengan diberlakukannya Peraturan Pemerintah Pengganti Undang-Undang Nomor 1 Tahun 2020 tentang kebijakan keuangan negara dan stabilitas sistem keuangan untuk penanganan Covid-19 dan/atau dalam rangka menghadapi ancaman yang membahayakan kesehatan dan perekenomian Indonesia. Peraturan tersebut berkaitan dengan dinyatakannya Covid-19 oleh Organisasi Kesehatan Dunia (World Health Organization) sebagai pandemi di seluruh negara, termasuk Indonesia. Ditetapkannya Perppu No 1 Tahun 2020 menandakan bahwa pemerintah melakukan penyelamatan kesehatan, yaitu dengan berfokus pada belanja barang (kesehatan), jaring pengaman sosial (social safety net) dan belanja pegawai (kesehatan).

Kewenangan pemerintah daerah dalam Perppu 1/2020 adalah Pemerintah Daerah diberikan kewenangan untuk melakukan pengutamaan penggunaan alokasi anggaran untuk kegiatan tertentu (refocusing), perubahan alokasi, dan penggunaan Anggaran Pendapatan dan Belanja Daerah dengan berpedoman kepada Peraturan Menteri Dalam Negeri. Salah satu daerah di Indonesia yang terdampak Covid-19 adalah Kota Bogor, Kota Bogor merupakan salah satu kota yang dekat dengan Ibukota dan menjadi salah satu kota dengan penularan melalui imported case yang berasal dari luar daerah. Pemerintah Kota Bogor dan Dinas Kesehatan Kota Bogor sudah melakukan antisipasi untuk menghadapi Covid-19, salah satunya melalui anggaran kesehatan Kota Bogor yang sudah disediakan. Proporsi Anggaran kesehatan Kota Bogor dalam anggaran belanja sebelum terdampak Covid-19 dicantumkan dalam Tabel 1.

Tabel 1. Proporsi Anggaran Sektor Kesehatan dalam Anggaran Belanja (dalam miliar) Kota Bogor Tahun 2015-2019.

\begin{tabular}{cccc}
\hline Tahun & $\begin{array}{c}\text { Anggaran Belanja Kota } \\
\text { Bogor (dalam triliun) }\end{array}$ & Anggaran Sektor Kesehatan & $\%$ \\
\hline 2015 & 2.312 & 169.528 & 7,3 \\
2016 & 2.426 & 191.979 & 7,9 \\
2017 & 2.597 & 206.622 & 8 \\
2018 & 2.651 & 225.321 & 8,5 \\
2019 & 2.855 & 296.028 & 10,4 \\
\hline
\end{tabular}

Sumber : Badan Keuangan Aset Daerah Kota Bogor Tahun 2015-2019 
Berdasarkan Tabel 1, proporsi anggaran sektor kesehatan dalam anggaran belanja pemerintah daerah Kota Bogor untuk realisasi anggaran kesehatan cenderung meningkat dari tahun 2015-2019. Alokasi anggaran kesehatan tertinggi terjadi pada tahun 2019 dengan persentase alokasi anggaran sebesar 10,4\%. Anggaran belanja Kota Bogor di tahun 2020 adalah sebesar 2,5 triliun dengan proporsi anggaran kesehatan sebesar 400 miliar (16\%), proporsi anggaran kesehatan Kota Bogor tersebut mayoritas dialokasikan untuk anggaran penanganan Covid-19 yaitu sebesar 300 miliar $^{1}$. Anggaran penanganan Covid-19 tersebut bersumber dari biaya tak terduga (BTT), pemangkasan anggaran organisasi perangkat daerah (OPD), dan pemangkasan anggaran DPRD Kota Bogor. ${ }^{2}$ Anggaran kesehatan yang disediakan oleh Pemerintah Kota Bogor di tahun 2020, mayoritas anggaran tersebut akan dialokasikan untuk penanganan Covid-19, sehingga anggaran kesehatan tersebut perlu dianggarkan dengan tepat oleh pemerintah Kota Bogor bersama dengan Dinas Kesehatan Kota Bogor, karena pada bulan Maret 2020 pemerintah menyatakan Covid-19 ada di Indonesia. Sehingga diperlukan perumusan strategi alokasi anggaran dinas kesehatan kota Bogor di era Covid-19.

\section{METODOLOGI PENELITIAN}

Penelitian ini dilaksanakan dalam kurun waktu empat (4) bulan yaitu dimulai pada bulan September sampai dengan bulan Desember 2020. Lokasi penelitian ini di Kota Bogor Provinsi Jawa Barat. Penelitian ini menggunakan dua jenis sumber data, yaitu data primer dan data skunder. Data primer yaitu data yang diperoleh melalui wawancara langsung dan pengisian kuesioner oleh responden yang terlibat dalam alokasi anggaran. Data sekunder yaitu data yang diperoleh dari publikasi instansi terkait, regulasi kebijakan, buku dan sumber literatur lainnya yang relevan dengan penelitian ini.

Metode pengumpulan data dalam penelitian ini yakni berdasarkan hasil wawancara dengan responden. Teknik pengumpulan data yang digunakan adalah wawancara dan kuisioner. Penyampaian kuesioner (angket) kepada responden yang dipilih dengan cara purposive sampling (dengan sengaja). Teknik ini digunakan untuk meminimalkan adanya bias dalam pengambilan data primer, karena informan merupakan orang-orang yang memahami serta terlibat langsung dalam pengambilan keputusan tentang hal yang diteliti. Subjek penelitian ini yaitu perwakilan dari Badan Keuangan Aset Daerah (BKAD) Kota Bogor, Dinas Kesehatan Kota Bogor dan Badan Perencanaan dan Pembangunan Daerah Kota Bogor (Bappeda). Pengisian kuesioner dilakukan sebanyak satu kali untuk menjawab pertanyaan penelitian yang ketiga.

Perumusan strategi dalam penelitian ini dengan menggunakan statistik deskriptif, statistik deskriptif berguna untuk menguraikan atau memberikan keterangan-keterangan mengenai suatu data atau keadaan atau fenomena, dengan kata statistik deskriptif berfungsi menerangkan keadaan, gejala, atau persoalan (Nasution 2017). Penelitian ini menerangkan keadaan, gejala, atau persoalan bagaimana kondisi anggaran di Dinas

\footnotetext{
${ }^{1}$ Kotabogor.go.id. APBD Kota Bogor bisa diakses terbuka di website.2019,06 September 2020

${ }^{2}$ Kompas.com.Pemerintah Kota Bogor Anggarkan Rp 300 miliar untuk Penanganan Covid-19.2020, 06 September 2020
} 
Kesehatan sebelum adanya Covid19 dan saat Covid-19 dan menerangkan keadaan penggunaan anggaran Covid-19 di Dinas Kesehatan Kota Bogor.

Analytical Hierarchy Process (AHP) merupakan model pendukung keputusan yang menguraikan masalah multi faktor atau multi kriteria yang kompleks.Model AHP merupakan salah satu bentuk pengambilan keputusan dengan peralatan utama model ini adalah hierarki (Falatehan 2016). AHP sering digunakan sebagai metode pemecahan masalah dibanding dengan metode yang lain karena alasan-alasan sebagai berikut :

1. Struktur yang berhierarki, sebagai konsekuesi dari kriteria yang dipilih, sampai pada subkriteria yang paling dalam.

2. Memperhitungkan validitas sampai dengan batas toleransi inkonsistensi berbagai kriteria dan alternatif yang dipilih oleh pengambil keputusan.

3. Memperhitungkan daya tahan output analisis sensitivitas pengambilan keputusan.

Hierarki didefinisikan sebagai suatu representasi dari sebuah permasalahan yang kompleks dalam suatu struktur multilevel dimana level pertama adalah tujuan, yang diikuti level faktor, aktor, kendala sampai dengan level terakhir dari alternatif. Menurut Kadarsah dan Ali (1998), langkah-langkah yang dilakukan dalam metode AHP adalah sebagai berikut:

1. Mengidentifikasi sistem dengan cara mempelajari faktor-faktor yang mempengaruhi,pelakunya,kendala dan kebijakan yang diinginkan berdasarkan atas referensi dan wawancara yang dilakukan saat penelitian.

2. Membuat struktur hierarki yang diawali dengan tujuan utama.

3. Menentukan skala nilai perbandingan yang menggambarkan kontribusi relatif atau pengaruh setiap elemen terhadap tujuan atau kriteria yang setingkat di atasnya. Skala nilai perbandingan dapat dilihat pada Tabel 2.

Tabel 2. Skala Penilaian Perbandingan Berpasangan

\begin{tabular}{c|l}
\hline $\begin{array}{c}\text { Intensitas } \\
\text { Kepentingan }\end{array}$ & \multicolumn{1}{c}{ Keterangan } \\
\hline 1 & $\begin{array}{l}\text { Kedua elemen sama pentingnya } \\
\text { Elemen yang satu sedikit lebih penting daripada elemen } \\
\text { yang lainnya } \\
\text { Elemen yang satu lebih penting daripada yang lainnya } \\
3\end{array}$ \\
$\begin{array}{l}\text { Satu elemen jelas lebih mutlak penting daripada elemen } \\
\text { lainnya } \\
\text { Satu elemen mutlak penting daripada elemen lainnya } \\
\text { Nilai-nilai antara dua nilai pertimbanganpertimbangan } \\
\text { yang berdekatan, nilai ini diberikan jika ada dua kompromi } \\
\text { di antara 2 pilihan. }\end{array}$ \\
\hline
\end{tabular}

Sumber : Saaty (1993)

\section{HASIL DAN PEMBAHASAN}

Analisis Kondisi Anggaran Dinas Kesehatan Kota Bogor di Era Covid-19

Alokasi anggaran Dinas Kesehatan Kota Bogor untuk pencegahan Covid-19 diantaranya meliputi belanja barang (kesehatan), belanja pegawai (kesehatan) dan jaring pengaman 
sosial. Belanja barang (kesehatan) mencakup belanja alat-alat kesehatan dan obatobatan, belanja pegawai (kesehatan) mencakup biaya tenaga kesehatan serta tim Covid19 Dinas Kesehatan dan jaring pengaman sosial berkaitan dengan pembayaran iuran kesehatan yang dibayarkan oleh Dinas Kesehatan Kota Bogor untuk masyarakat yang tergolong sebagai penerima subsidi. Total Anggaran Belanja Barang (Kesehatan) dan Belanja Pegawai (Kesehatan) pada Dinas Kesehatan Kota Bogor saat Covid-19 di tahun 2020 dicantumkan pada Tabel 3.

Tabel 3.Total Anggaran Belanja Barang (Kesehatan), Belanja Pegawai (kesehatan) dan Jaring Pengaman Sosial (JPS) pada Dinas Kesehatan Kota Bogor Tahun 2020 (dalam miliar)

\begin{tabular}{lrrr} 
Bulan & $\begin{array}{c}\text { Belanja Barang } \\
\text { (kesehatan) }\end{array}$ & $\begin{array}{c}\text { Belanja Pegawai } \\
\text { (kesehatan) }\end{array}$ & Jaring pengaman Sosial \\
\hline Januari & 2.956 & 3.102 & 8.121 \\
Februari & 706 & 4.630 & 8.271 \\
Maret & 2.2172 & 4.632 & 8.321 \\
April & 6.682 & 4.680 & 8.324 \\
Mei & 6.848 & 7.689 & 6.676 \\
Juni & 3.893 & 4.671 & 6.829 \\
Juli & 40.453 & 4.712 & 2.990 \\
Agustus & 9.925 & 7.600 & 4.693 \\
September & 20.064 & 4.591 & 4.431 \\
Oktober & 6.845 & 4570 & 2.955 \\
November & 7.086 & 4.590 & 2.975 \\
Desember & 43.367 & 6.274 & 5.269 \\
\hline \multicolumn{1}{c}{ Total } & $\mathbf{1 7 0 . 9 9 7}$ & $\mathbf{6 1 . 7 4 1}$ & $\mathbf{6 9 . 8 5 3}$ \\
\hline \multicolumn{1}{c}{ Rataan } & $\mathbf{1 7 . 1 0 0}$ & $\mathbf{6 . 1 7 4}$ & $\mathbf{6 . 9 8 5}$ \\
\hline
\end{tabular}

Sumber : Dinas Kesehatan Kota Bogor Tahun Anggaran 2020

Berdasarkan informasi pada Tabel 3 total alokasi anggaran belanja barang (kesehatan) relatif lebih tinggi dibandingkan dengan alokasi anggaran belanja pegawai (kesehatan) dan jaring pengaman sosial. Total alokasi anggaran belanja barang (kesehatan) yaitu sebesar Rp 170.997 miliar dengan alokasi anggaran tertinggi pada bulan Desember 2020. Anggaran belanja barang (kesehatan) pada bulan Desember 2020 yaitu sebesar Rp 43.367 miliar, alokasi anggaran mengalami peningkatan karena adanya peningkatan swab dan jumlah masyarakat positif Covid-19 yang perlu isolasi mandiri, sehingga terjadi peningkatan belanja barang yang diperlukan untuk penganan Covid-19.

Total alokasi anggaran belanja pegawai (kesehatan) yaitu sebesar Rp 61.741 miliar dengan alokasi anggaran tertinggi di bulan Mei 2020. Anggaran belanja pegawai (kesehatan) pada bulan Mei 2020 yaitu sebesar Rp 7.689 miliar. Anggaran belanja pegawai (kesehatan) mengalami peningkatan pada bulan Mei 2020 karena adanya pembiayaan tenaga kesehatan yang menangani langsung masyarakat terdampak Covid19 serta pembiayaan tim Covid-19 Dinas Kesehatan Kota Bogor. Total alokasi anggaran jaring pengaman sosial yaitu sebesar Rp 69.853 miliar dengan alokasi anggaran tertinggi pada bulan April 2020. Anggaran jaring pengaman sosial pada bulan April 
2020 yaitu sebesar Rp 8.324 miliar. Anggaran jaring pengaman sosial mengalami peningkatan di bulan April 2020 karena adanya peningkatan Penerima Bantuan Iuran (PBI) BPJS yang didaftarkan oleh Pemerintah Daerah Kota Bogor. Grafik anggaran belanja dan jaring pengaman sosial (JPS) pada dinas kesehatan Kota Bogor Tahun 2020 dicantumkan pada Gambar 3.

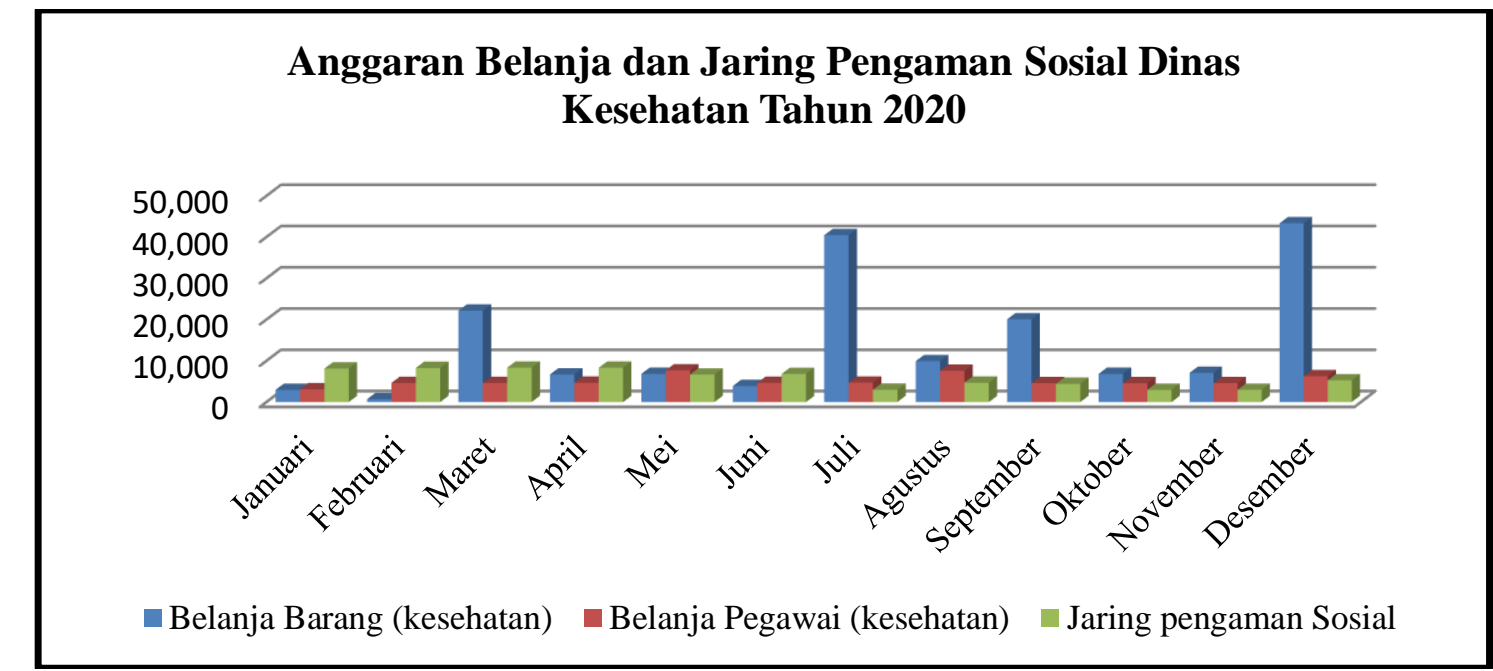

Gambar 3. Total Anggaran Belanja Barang (Kesehatan), Belanja Pegawai (kesehatan) dan Jaring Pengaman Sosial (JPS) pada Dinas Kesehatan Kota Bogor Tahun 2020

Kondisi anggaran yang meliputi anggaran belanja barang (kesehatan), belanja pegawai (kesehatan) dan jaring pengaman sosial di era Covid-19 di tahun 2020 relatif lebih tinggi. Kondisi anggaran di era Covid-19 menunjukkan bahwa total anggaran belanja barang (kesehatan) lebih tinggi dibandingkan total anggaran belanja pegawai (kesehatan) dan jaring pengaman sosial. Kondisi anggaran belanja sebelum Covid-19 menunjukkan Total anggaran belanja barang (kesehatan) lebih tinggi dibandingkan anggaran belanja pegawai (kesehatan) dan jaring pengaman sosial. Kondisi ini menunjukkan bahwa anggaran belanja barang (kesehatan) lebih banyak dikeluarkan dibandingkan anggaran yang lain.Total anggaran belanja barang (kesehatan),belanja pegawai (kesehatan) dan jaring pengaman sosial pada Dinas Kesehatan Kota Bogor Tahun 2015-2019 dicantumkan pada Tabel 4.

Tabel 4.Total Anggaran Belanja Barang (Kesehatan), Belanja Pegawai (kesehatan) dan Jaring Pengaman Sosial (JPS) pada Dinas Kesehatan Kota Bogor Tahun 2015-2019 (dalam miliar)

\begin{tabular}{cccc}
\hline Tahun & $\begin{array}{c}\text { Belanja Barang } \\
\text { (kesehatan) }\end{array}$ & $\begin{array}{c}\text { Belanja Pegawai } \\
\text { (kesehatan) }\end{array}$ & $\begin{array}{c}\text { Jaring Pengaman } \\
\text { Sosial }\end{array}$ \\
\hline 2015 & 71.187 & 4.742 & 6.517 \\
2016 & 83.907 & 5.305 & 1.821 \\
2017 & 103.988 & 5.405 & 2.012 \\
2018 & 116.675 & 8.038 & 4.995 \\
2019 & 13.7552 & 15.036 & 4.382 \\
\hline Total & $\mathbf{5 1 3 . 3 0 9}$ & $\mathbf{3 8 . 5 2 6}$ & $\mathbf{1 9 . 7 2 7}$ \\
\hline Rataan & $\mathbf{1 0 2 . 6 6 2}$ & $\mathbf{7 . 7 0 5}$ & $\mathbf{3 . 9 4 5}$ \\
\hline
\end{tabular}

Sumber : Dinas Kesehatan Kota Bogor Tahun Anggaran 2015-2019 
Berdasarkan informasi pada Tabel 4 total anggaran belanja barang (kesehatan) tertinggi adalah di tahun 2019 yaitu sebesar Rp 13.7552 miliar dan total terendah adalah di tahun 2015 yaitu sebesar Rp 71.187 miliar. Selama rentang waktu 5 tahun rata-rata total anggaran belanja barang (kesehatan) yaitu sebesar Rp 102.662 miliar. Total anggaran belanja pegawai cenderung meningkat dari tahun 2015-2018 dan mengalami penuruan di tahun 2019, total anggaran belanja pegawai (kesehatan) tertinggi adalah di tahun 2019 yaitu sebesar Rp 15.036 miliar dengan rata-rata total anggaran belanja pegawai (kesehatan) adalah sebesar Rp 7.705 miliar. Anggaran jaring pengaman sosial di Dinas Kesehatan cenderung fluktuatif selama rentang 5 tahun. Total anggaran tertinggi terjadi pada tahun 2015 yaitu sebesar Rp 6.517 miliar dan total anggaran terendah terjadi pada tahun 2016 yaitu sebesar Rp 1.821 miliar. Rata-rata total anggaran jaring pengaman sosial selama 5 tahun adalah sebesar Rp 3.945 miliar. Perbandingan kondisi anggaran saat era Covid-19 dan sebelum era Covid-19 menunjukkan bahwa adanya realokasi dan refocusing anggaran, sehingga total anggaran di tahun 2020 lebih besar dibandingkan tahun sebelumnya. Grafik anggaran belanja dan jaring pengaman sosial (JPS) pada dinas kesehatan Kota Bogor Tahun 2015-2019 dicantumkan pada Gambar 4.

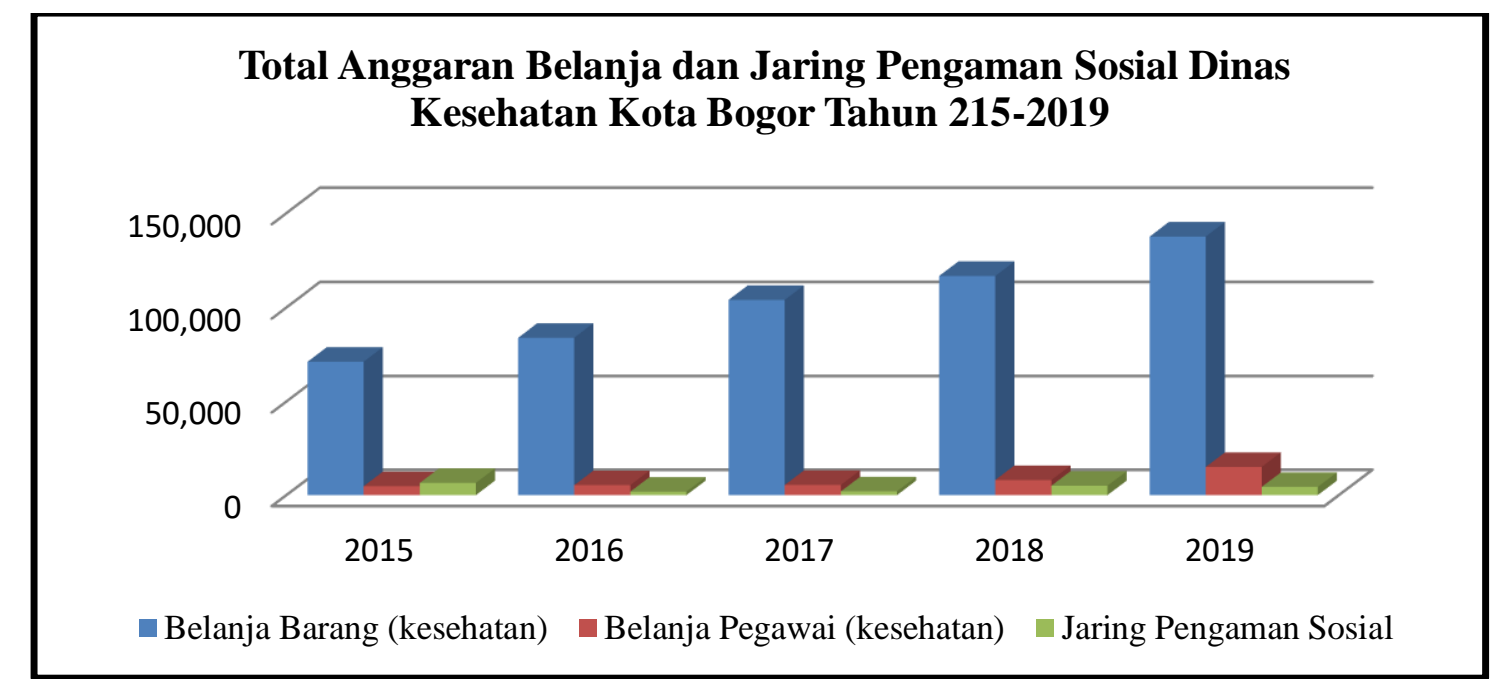

Gambar 4. Total Anggaran Belanja dan Jaring Pengaman Sosial Dinas Kesehatan Kota Bogor Tahun 2015-2019.

Perbandingan anggaran belanja dan jaring pengaman sosial di tahun 2020 saat Covid-19 dengan anggaran belanja dan jaring pengaman sosial tahun sebelumnya yaitu tahun 2019 terjadi kenaikan total anggaran di tahun 2020. Total anggaran belanja barang (kesehatan) di tahun 2019 yaitu sebesar Rp. 13.7552 miliar, anggaran belanja pegawai (kesehatan) yaitu sebesar Rp 15.036 miliar dan jaring pengaman sosial yaitu sebesar Rp 15.036 miliar. Total anggaran belanja barang (kesehatan) di tahun 2020 yaitu sebesar Rp 170.997 miliar, anggaran belanja pegawai (kesehatan) yaitu sebesar Rp 61.741 miliar dan jaring pengaman sosial yaitu sebesar Rp 69.853 miliar. Kenaikan ini dikarenakan besarnya belanja Dinas Kesehatan Kota Bogor karena efek Covid-19. Efek Covid-19 ini menyebabkan peningkatan masyarakat positif Covid-19 yang mengharuskan Dinas Kesehatan Kota Bogor mengeluarkan anggaran yang berfokus untuk pencegahan penyebaran Covid-19. Grafik total anggaran belanja dan jaring pengaman sosial tahun 2019 dan tahun 2020 pada Gambar 5. 


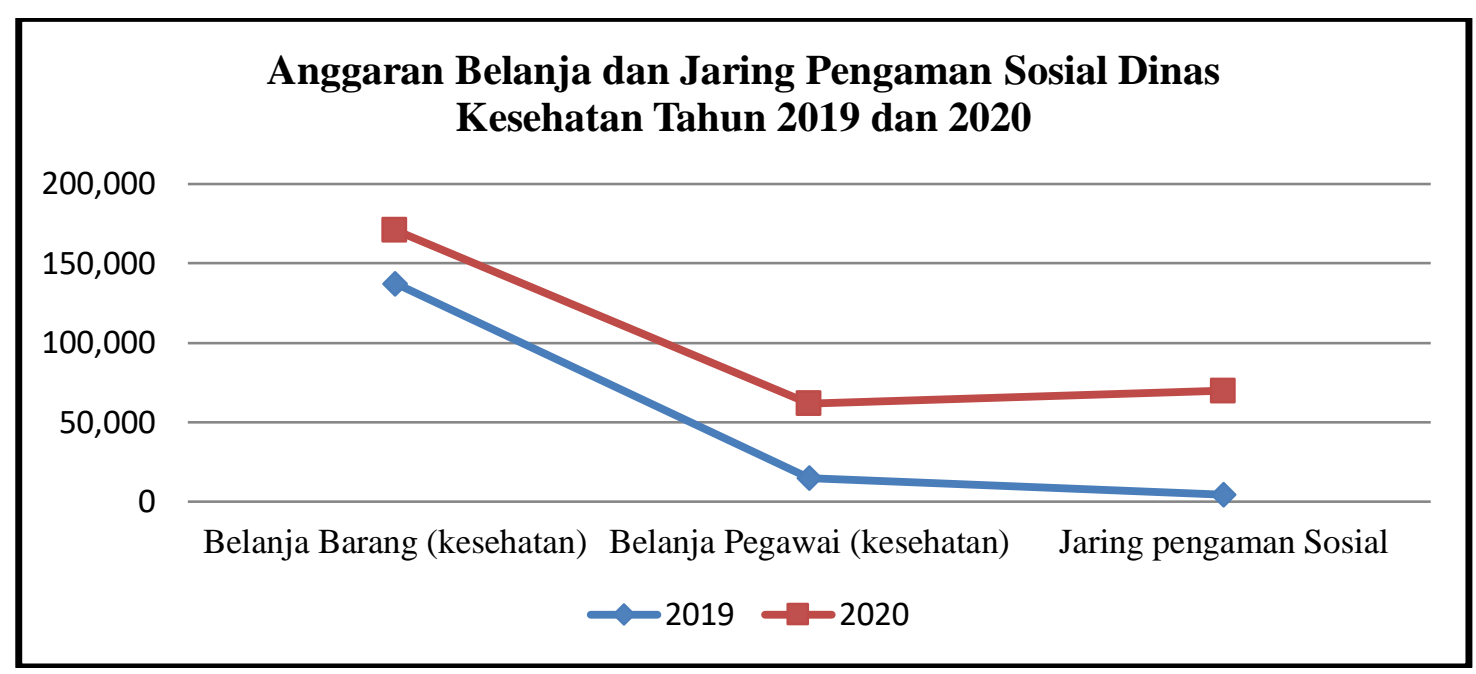

Gambar 5. Grafik Total Anggaran Belanja dan Jaring Pengaman Sosial Tahun 2019 dan Tahun 2020

Alokasi anggaran kesehatan yang dikeluarkan oleh Pemerintah Kota Bogor mayoritas dianggarkan untuk penanganan Covid-19 di Kota Bogor. Anggaran kesehatan yang berasal dari anggaran pendapatan belanja daerah berfokus untuk meminimalisir jumlah masyarakat positif Covid-19 melalui belanja barang (kesehatan), belanja pegawai (kesehatan) dan jaring pengaman sosial. Jumlah masyarakat positif Covid-19 di Kota Bogor dari bulan Maret sampai bulan Desember 2020 terus meningkat dengan angka tertinggi di bulan Desember 2020 yaitu sebesar 3.302 orang, hal ini disebabkan karena Covid-19 menular melalui udara dan tingginya mobilitas masyarakat yang menyebabkan imported case di Kota Bogor. Anggaran belanja dan jaring pengaman sosial berdampak pada meningkatnya jumlah masyarakat sembuh Covid-19, angka kesembuhan tertinggi pada bulan Desember 2020 yaitu sebesar 3.581 orang. Data masyarakat positif dan masyarakat sembuh Covid-19 di Kota Bogor pada bulan Maret sampai bulan Desember tahun 2020 pada Gambar 6.

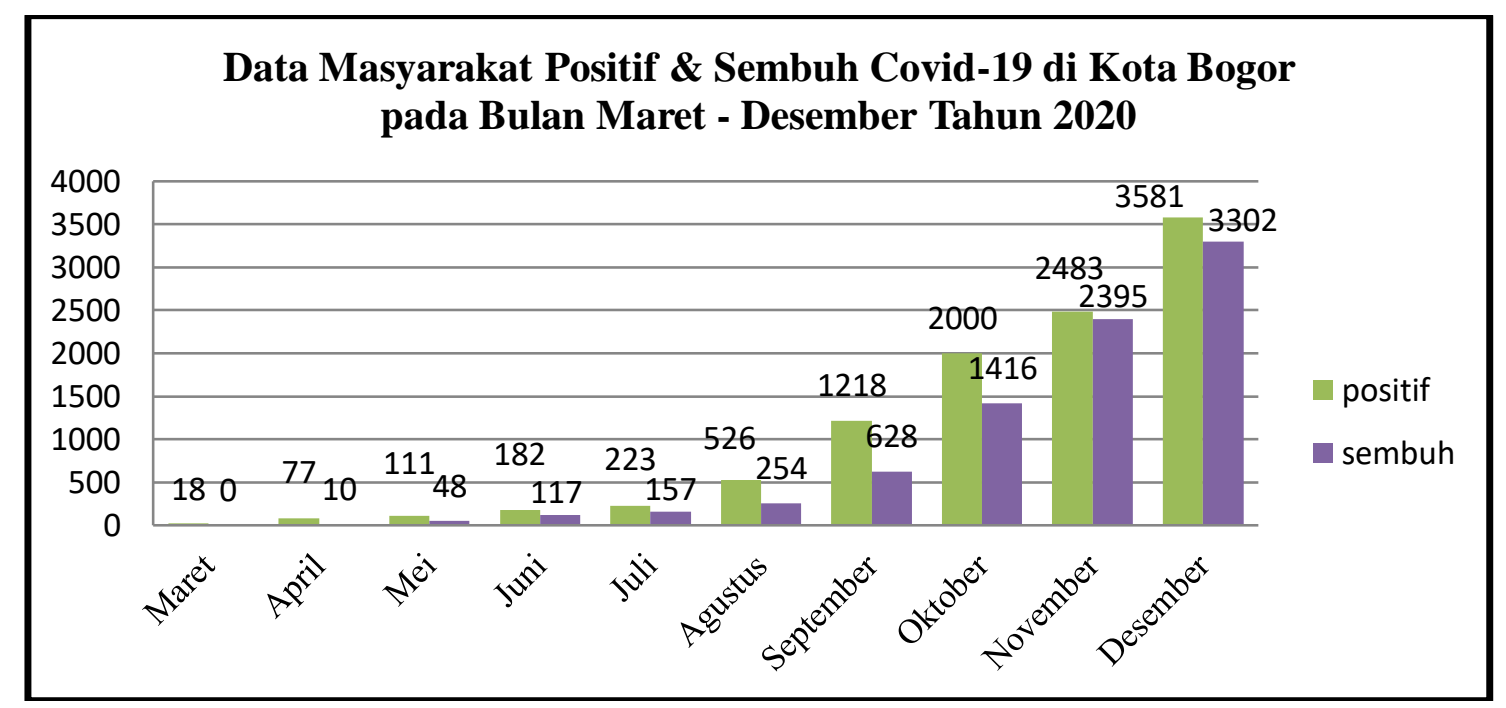

Gambar 6. Data Masyarakat Positif dan Masyarakat Sembuh Covid-19 di Kota Bogor pada Bulan Maret - Desember Tahun 2020

(Sumber: Pengolahan Data Sekunder Tahun2020) 


\section{Penggunaan Anggaran Covid-19 Dinas Kesehatan Kota Bogor}

Dinas Kesehatan Kota Bogor mengaloaksikan anggaran kesehatan berfokus menangani pencegahan penyebaran Covid-19 melalui belanja barang (kesehatan), belanja pegawai (kesehatan) dan jaring pengaman sosial. Anggaran kesehatan dialokasikan sesuai dengan prioritas dan kegiatan yang dibutuhkan untuk pencegahan penyebaran Covid-19. Kegiatan yang dilakukan melibatkan Pemerintah Daerah Kota Bogor, Dinas Kesehatan Kota Bogor, Tim Covid-19 Dinas Kesehatan Kota Bogor, Aparat Keamanan Kota Bogor dan Masyarakat Kota Bogor.

Anggaran belanja barang (kesehatan) difokuskan untuk pengeluaran obat-obatan, vitamin, masker, tempat cuci tangan, APD, termometer dan alat swab. Pengeluaran obat-obatan dan vitamin digunakan sebagai upaya penyembuhan masyarakat positif Covid-19. Pengeluaran untuk masker, pembuatan sarana tempat cuci tangan dan termometer yang merupakan sarana yang diberikan untuk masyarakat sebagai upaya pencegahan penyebaran Covid-19. Anggaran belanja barang (kesehatan) bertujuan untuk seluruh kegiatan berupa pengecekan hasil swab Covid-19, upaya pencegahan penyebaran Covid-19 dan isoman.

Anggaran belanja pegawai (kesehatan) difokuskan untuk pembiayaan tim Covid-19 Dinas Kesehatan Kota Bogor yang bertugas sebaagi pihak yang membantu memfasilitasi kegiatan swab yang berkaitan dengan lokasi ujio swab,alat kesehatan dan pengecekan uji swab dan anggaran belanja pegawai (kesehatan) juga difokuskan untuk pembiayaan tenaga kesehatan Covid-19 yang bekerja di Puskesmas,Labkesda dan Isoman (Lido). Penggunaan anggaran jaring pengaman sosial di Dinas Kesehatan Kota Bogor yaitu sebagai pembiayaan iuran BPJS yang ditujukan kepada masyarakat yang terkena Covid-19 yang terdaftar oleh Pemerintah Daerah Kota Bogor sebagai Penerima Bantuan Iuran (PBI) BPJS. Data jenis belanja,kegiatan dan sasarannya dicantumkan pada Tabel 5.

Tabel 5. Jenis Belanja,Kegiatan dan Sasaran yang Terlibat

\begin{tabular}{|c|c|c|c|}
\hline $\begin{array}{c}\text { Jenis } \\
\text { Belanja }\end{array}$ & $\begin{array}{c}\text { Jenis } \\
\text { Barang/ } \\
\text { Jasa }\end{array}$ & Kegiatan & Sasaran Terlibat \\
\hline $\begin{array}{l}\text { Belanja } \\
\text { Barang } \\
\text { (kesehatan) }\end{array}$ & $\begin{array}{l}\text { Pembelian } \\
\text { obat- } \\
\text { obatan,vita } \\
\text { min, } \\
\text { masker, } \\
\text { APD, alat } \\
\text { kesehatan, } \\
\text { hand } \\
\text { sanitizer,ter } \\
\text { mometer } \\
\text { dan tempat } \\
\text { cuci tangan }\end{array}$ & $\begin{array}{l}\text { - Perjalanan Dinas } \\
\text { (pengiriman sampel swab } \\
\text { Covid-19) } \\
\text { - Kebutuhan pemeriksaan } \\
\text { laboratorium dan pembayaran } \\
\text { Lab IPB untuk pemeriksaan } \\
\text { swab Covid-19 } \\
\text { - Peningkatan dan } \\
\text { pengembangan pelayanan } \\
\text { informasi publik dan } \\
\text { - Upaya kesehatan } \\
\text { lingkungan (penyediaan } \\
\text { sarana tempat cuci tangan) } \\
\text { - Penyediaan isoman (Lido) }\end{array}$ & $\begin{array}{l}\text { OPD, Faskes } \\
\text { (puskesmas dan } \\
\text { isoman), Public } \\
\text { Safety Center dan } \\
\text { Masyarakat }\end{array}$ \\
\hline
\end{tabular}


Tabel 5. Lanjutan

\begin{tabular}{llll}
\hline \multicolumn{1}{c}{$\begin{array}{c}\text { Jenis } \\
\text { Belanja }\end{array}$} & $\begin{array}{c}\text { Jenis } \\
\text { Barang/ } \\
\text { Jasa }\end{array}$ & \multicolumn{1}{c}{ Kegiatan } & Sasaran Terlibat \\
\hline $\begin{array}{l}\text { Belanja } \\
\text { pegawai } \\
\text { (kesehatan) }\end{array}$ & $\begin{array}{l}\text { Pembiayaan } \\
\text { jasa tenaga } \\
\text { kesehatan } \\
\text { Covid-19 }\end{array}$ & $\begin{array}{l}\text { Insentif Tim Covid-19 Dinas } \\
\text { Kesehatan,Puskesmas, } \\
\text { Labkesda dan Isoman (Lido) }\end{array}$ & $\begin{array}{l}\text { Tim Covid-19 } \\
\text { Dinkes dan tenaga } \\
\text { kesehatan Covid-19 }\end{array}$ \\
$\begin{array}{l}\text { Jaring } \\
\text { Pengaman } \\
\text { Sosial }\end{array}$ & $\begin{array}{l}\text { Pembiayan } \\
\text { peserta PBI }\end{array}$ & $\begin{array}{l}\text { Klaim iuran BPJS ke } \\
\text { masyarakat peserta PBI BPJS }\end{array}$ & $\begin{array}{l}\text { Masyarakat Kota } \\
\text { Bogor yang terdaftar } \\
\text { sebagai peserta PBI } \\
\text { BPJS oleh Pemda } \\
\text { Kota Bogor }\end{array}$ \\
\hline
\end{tabular}

\section{Strategi Dinas Kesehatan Kota Bogor dalam Menghadapi Covid-19 berdasarkan Anggaran yang Ada}

Perumusan strategi alokasi anggaran di era Covid-19 pada Dinas Kesehatan Kota Bogor menggunakan metode Analithycal Hierarchy Process (AHP). Struktur hierarki dalam metode AHP mencakup level fokus yaitu tujuan yang diharapkan dapat tercapai melalui faktor - faktor yang mempengaruhi, peran utama perwakilannya dalam penelitian ini sebagai responden, kendala yang dihadapi dan beberapa alternatif strategi yang telah diprioritaskan. Berdasarkan Peraturan Pemerintah Pengganti Undang-Undang Nomor 1 Tahun 2020 disebutkan bahwa pemerintah melakukan penyelamatan kesehatan yaitu dengan berfokus pada belanja barang (kesehatan), jaring pengaman sosial (JPS), dan belanja pegawai (kesehatan). Ketiga hal tersebut dipilih sebagai faktor pada struktur Hierarki AHP dalam penelitian ini.

Pihak utama yang dipilih sebagai aktor dalam penelitian ini adalah Dinas Kesehatan Kota Bogor, Badan Perencanaan dan Pembangunan Daerah (Bappeda) Kota Bogor dan Badan Keuangan Aset Daerah (BKAD) Kota Bogor. Ketiga pihak tersebut mempunyai pengaruh besar dalam penyusunan strategi alokasi anggaran Dinas Kesehatan di era Covid-19. Dinas Kesehatan Kota Bogor sebagai dinas terkait yang menangani secara langsung permasalahan pada sektor kesehatan akibat pandemi Covid-19 di Kota Bogor. Pihak utama selanjutnya yaitu Badan Perencanaan dan Pembangunan Daerah (Bappeda) Kota Bogor, dan Badan Keuangan Aset Daerah (BKAD) Kota Bogor sekaligus sebagai Tim Anggaran Pemerintah Daerah (TAPD) Kota Bogor. Peranan Bappeda adalah sebagai lembaga yang mempunyai kewenangan dalam penyusunan rencana kegiatan Pemerintah Kota Bogor, dan peranan BKAD sekaligus TAPD adalah terkait kebijakan pengelolaan keuangan Pemerintah Kota Bogor.

Berdasarkan hasil wawancara bersama responden mengenai strategi alokasi anggaran pada Dinas Kesehatan Kota Bogor di era Covid-19 terdapat tiga kendala utama yang dihadapi responden dalam penyusunan alokasi anggaran. Kendala pertama adalah realokasi dan refocusing anggaran, yaitu anggaran belanja yang tidak bisa direalisasikan saat terjadinya pandemi Covid-19, anggaran belanja tersebut kemudian difokuskan 
untuk kegiatan di sektor kesehatan. Kendala ke-dua adalah waktu penyusunan anggaran, yaitu mengenai ketepatan waktu penyusunan anggaran saat Covid-19. Kendala ketiga adalah kemampuan APBD Kota Bogor, besar anggaran yang dikeluarkan untuk belanja di sektor kesehatan perlu disesuaikan dengan pendapatan yang dimiliki oleh Kota Bogor,. Kendala yang paling mendominasi berdasarkan analisis menggunakan AHP adalah kemampuan APBD yang dimiliki Kota Bogor,yaitu dengan penilaian 0.48. Kepala Bidang Perencanaan,Pengendalian, Evaluasi Pemerintah Daerah (PPEPD) Bappeda Kota Bogor saat wawancara menyatakan "anggaran yang dikeluarkan pemerintah Kota Bogor untuk belanja pengeluaran Covid-19 harus tetap sesuai dengan pendapatan yang dimiliki oleh Kota Bogor agar balance" .

Alternatif solusi yang dapat dijadikan strategi utama guna menyelesaikan kendala yang ada disusun berdasarkan hasil wawancara dengan responden. Alternatif-alternatif solusi tersebut dihimpun dan dianalisa dari hasil wawancara serta diskusi dengan narasumber, kemudian berbagai pilihan solusi tersebut disarikan ke dalam tiga buah alternatif strategi. Alternatif strategi yang ditawarkan kepada responden yaitu:

1. Melakukan penyesuaian (realokasi dan refocusing) anggaran belanja pemerintah daerah oleh Dinas teknis sesuai dengan arahan Pemerintah Kota Bogor.

2. Percepatan Pembahasan dalam penyusunan perubahan APBD TA. 2020 oleh Pemerintah Kota Bogor.

3. Penyusunan perubahan APBD T.A 2020 sesuai dengan prioritas belanja pada sektor kesehatan di Kota Bogor.

Penyesuaian anggaran belanja terkait adanya realokasi dan refocusing anggaran merupakan salah satu alternatif strategi untuk mengatasi kendala. Penyesuaian anggaran ialah anggaran yang sudah dialokasikan Pemerintah Kota Bogor untuk suatu kegiatan di tahun 2020, namun anggaran tersebut diputuskan untuk dianggarkan sebagai belanja kegiatan di sektor kesehatan. Realokasi dan refocusing ini bertujuan untuk mengatasi masalah Covid-19 di Kota Bogor. Kendala terkait realokasi dan refocusing anggaran diharapkan mampu diatasi melalui penyesuaian anggaran realokasi dan refocusing yang ada di Dinas Kesehatan Kota Bogor.

Percepatan pembahasan dalam penyusunan perubahan APBD TA. 2020 oleh Pemerintah Kota Bogor merupakan alternatif strategi berikutnya. Strategi ini diperlukan terkait kendala mengenai ketepatan ketepatan waktu penyusunan anggaran saat Covid19. Pembahasan penyusunan mengenai perubahan APBD saat masa pandemi perlu dilakukan dengan cepat, sehingga proses belanja Pemerintah Kota Bogor dalam mengatasi Covid-19 dapat segera direalisasikan.

Alternatif strategi selanjutnya yaitu penyusunan perubahan APBD T.A 2020 sesuai dengan prioritas belanja pada sektor kesehatan di Kota Bogor. Anggaran belanja yang dapat dikeluarkan pemerintah Kota Bogor untuk sektor kesehatan perlu mencermati ketersediaan dana yang ada pada APBD pada waktu tersebut. Kesesuain jumlah anggaran belanja yang dikeluarkan dengan pendapatan yang dimiliki mensyaratkan perlu adanya prioritas belanja di sektor kesehatan Kota Bogor.

Pemilihan strategi utama oleh responden mengarah pada pemilihan penyesuaian anggaran belanja pemerintah daerah oleh Dinas teknis sesuai dengan arahan pemerintah 
Kota Bogor. Strategi ini mendapat dukungan terbesar dari para responden dengan nilai 0.45 , sehingga strategi tersebut menjadi strategi dengan prioritas pertama untuk direkomendasikan kepada pemerintah Kota Bogor dalam upaya alokasi anggaran Dinas Kesehatan Kota bogor di era Covid-19. Kepala Sub Bagian Rencana Lapangan Dinas Kesehatan Kota Bogor menyatakan "realokasi dan refocusing anggaran dilakukan dengan tujuan anggaran dikeluarkan sesuai dengan program dan kegiatan yang dibutuhkan oleh Dinas Kesehatan Kota Bogor, sehingga anggaran yang dikeluarkan tepat sesuai dengan sasaran ". Hasil Penelitian AHP untuk Strategi Alokasi Anggaran Dinas Kesehatan Kota Bogor di Era Covid-19 dicantumkan pada Gambar 7.

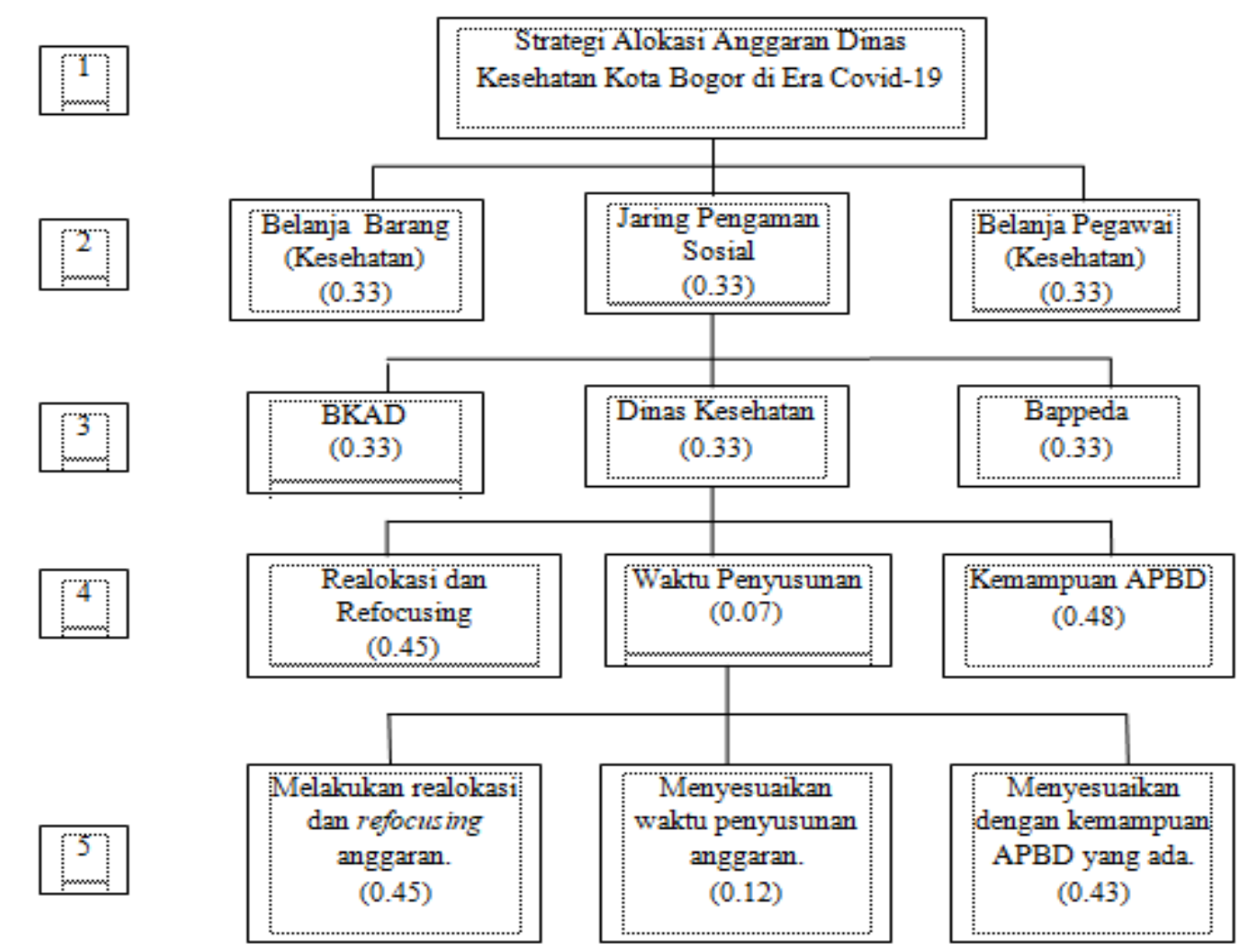

Gambar 7. Hasil Penelitian AHP untuk Strategi Alokasi Anggaran Dinas Kesehatan Kota Bogor di Era Covid-19

Keterangan :

1 : Tujuan yang ingin dicapai

2: Aspek yang mempengaruhi pemilihan strategi

3 : Pihak yang berpengaruh dalam pengambilan keputusan

4 : Kendala-kendala yang dihadapi

5 : Alternatif-alternatif strategi

Sumber: Pengolahan Data Primer (2020)

\section{SIMPULAN}

Berdasarkan Peraturan Pemerintah Pengganti Undang-Undang Nomor 1 Tahun 2020 tentang kebijakan keuangan negara dan stabilitas sistem keuangan untuk penanganan Covid-19 dan/atau dalam rangka menghadapi ancaman yang membahayakan kesehatan 
dan perekenomian Indonesia. Peraturan tersebut berkaitan dengan dinyatakannya Covid-19 oleh Organisasi Kesehatan Dunia (World Health Organization) sebagai pandemi di seluruh negara, termasuk Indonesia. Ditetapkannya Perppu No 1 Tahun 2020 menandakan bahwa pemerintah melakukan penyelamatan kesehatan, yaitu dengan berfokus pada belanja barang (kesehatan), jaring pengaman sosial (social safety net), dan belanja pegawai (kesehatan).

Melalui Perppu No 1 Tahun 2020 pemerintah daerah Kota Bogor dalam upaya mencegah penyebaran Covid-19 mengalokasikan anggaran serta tujuan penggunaan anggaran tersebut melalui Dinas Kesehatan Kota Bogor. Hasil penelitian ini menunjukkan bahwa pengeluaran anggaran belanja barang (kesehatan) di tahun 2020 sebesar Rp170.997 miliar , anggara belanja pegawai (kesehatan) sebesar Rp 61.741 miliar, sedangkan anggaran jaring pengaman sosial yaitu sebesar Rp 69.853 miliar. Pengeluaran belanja barang (kesehatan) di Dinas Kesehatan Kota Bogor saat Covid-19 lebih tinggi dibanding pengeluaran anggaran pegawai (kesehatan) dan jaring pengaman sosial, penggunaan anggaram belanja barang (kesehatan) difokuskan untuk pembelian alat kesehatan. Sedangkan pengeluaran anggaran belanja pegawai (kesehatan) difokuskan untuk pembiayaan tenaga kesehatan Covid-19 dan tim Covid-19 Dinas Kesehatan Kota Bogor, pengeluaran anggaran jaring pengaman sosial difokuskan untuk Penerima Bantuan Iuran BPJS saat Covid-19. Anggaran kesehatan yang dikeluarkan pemerintah daerah Kota Bogor melalui Dinas Kesehatan untuk belanja barang, belanja pegawai dan jaring pengaman sosial (JPS) cukup mengindikasikan bahwa anggaran yang dikeluarkan mampu meningkatkan jumlah masyarakat yang sembuh dari Covid19, namun hal ini tidak mencegah kenaikan masyarakat yang positif Covid-19 di Kota Bogor.

Alternatif strategi alokasi anggaran Dinas Kesehatan Kota Bogor berdasarkan anggaran yang ada berdasarkan hasil analisis AHP yaitu melakukan realokasi dan refocusing anggaran dengan prioritas belanja pada sektor kesehatan Kota Bogor. Kendala utama dari strategi alokasi anggaran ini yaitu kemampuan anggaran yang dimiliki oleh Pemerintah Daerah Kota Bogor yang bertujuan anggaran tersebut dikeluarkan sesuai dengan belanja yang dibutuhkan.

\section{DAFTAR PUSTAKA}

Falatehan AF. 2016. Analytical Hierarchy Process(AHP): Teknik Pengambilan Keputusan untuk Pembangunan Daerah. Yogyakarta: Indomedia Pustaka

Kadarsah S,Ali MR. 1998. Sistem Pendukung Keputusan. Bandung: PT Remaja Rosdakarya.

[Kemenkeu] Kementrian Keuangan. 2020. Peraturan Pemerintah Pengganti UndangUndang Nomor 1 Tahun 2020 tentang Kebijakan Keuangan Negara dan Stabilitas Sistem Keuangan untuk Penanganan Pandemi Corona Virus Disease 2019 (Covid-19). Jakarta (ID) : Sekretaris Negara.

Nasution, LM. 2017. Statistik Deskriptif. Jurnal Hikmah, 14 (1), 49-55. 
Saaty TL. 1993. Pengambilan Keputusan Bagi Para Pemimpin : Proses Hirarki Analitik untuk Pengambilan Keputusan dalam Situasi yang Kompleks. SetionoL,Penerjemah. Jakarta (ID): PT. Pustaka Binaman Pressindo. 